Левчишина О. В., канд. мед. наук, лікар-хірург відділення рентгенхірургічних методів діагностики та лікування захворювань серця і судин

Бешляга В. М., канд. мед. наук, лікар ультразвукової діагностики

Руденко А. В., д-р мед. наук, академік НАН України, заступник директора

ДУ «Національний інститут серцево-судинної хірургії імені М. М. Амосова НАМН України», м. Київ, Україна

\title{
Клінічний випадок поєднання великої істинної аневризми лівого шлуночка, ускладненої формуванням псевдоаневризми
}

\begin{abstract}
Резюме. У статті представлений клінічний випадок виявлення та оперативного лікування поєднання істинної та несправжньої аневризми лівого шлуночка в пацієнта після перенесеного гострого інфаркту міокарда. Пацієнт К. поступив у клініку з діагнозом ішемічної хвороби серця. При ехокардіографії виявлено аневризму задньої стінки лівого шлуночка. Позаду задньої стінки лівого шлуночка візуалізувалася додаткова порожнина у вигляді осумкованого утворення з рідиною. Пацієнту К. в НІССХ імені М. М. Амосова НАМН України виконано в екстреному порядку коронаровентрикулографію. На ангіограмі лівої коронарної артерії виявлено помірні (до 50 \%) стенози середньої третини огинаючої гілки, передньої міжшлуночкової гілки та діагональної гілки першого порядку. На ангіограмі правої коронарної артерії візуалізується оклюзія дистальної третини артерії. При лівій вентрикулографії в правій косій та лівій боковій проекціях виявлено, що порожнина лівого шлуночка значно розширена та деформована, скоротлива здатність його стінок різко знижена переважно за рахунок базальних відділів, де визначається аневризматичне вип'ячування з виходом контрастної речовини в порожнину перикарда. У зв'язку із загрозою тампонади пацієнту К. в екстреному порядку виконано резекцію задньобокової аневризми лівого шлуночка зі штучним кровообігом. За даними ехокардіографії після проведеної пластики деформація порожнини лівого шлуночка відсутня, мітральний клапан збережений, загальна скоротливість покращилась. Пацієнт переведений до кардіологічного стаціонару за місцем проживання для проведення подальшої реабілітації. Точна діагностика та ургентне оперативне лікування дозволили пацієнту не лише вижити, а й зберегти якість життя.
\end{abstract}

Ключові слова: аневризма лівого шлуночка, гострий інфаркт міокарда, ішемічна хвороба серия.

Вступ. Постінфарктна аневризма лівого шлуночка (АЛШ) - це організований фіброзний рубець, позбавлений м'язової тканини. Під час систоли сегменти стінок, що залучені в патологічний процес, акінетичні або дискінетичні [3]. Аневризми серця утворюються після перенесеного трансмурального інфаркту міокарда в результаті оклюзії однієї з великих гілок коронарних артерій. Травми та поранення серця з ураженням коронарних артерій як причина розвитку аневризм серця становлять менше $1 \%$ випадків [2].

Класифікація АЛШ: 1) за часом формування: гострі (до 1 місяця) та хронічні; 2) за морфологією: фіброзні та фіброзно-м'язові; 3) за локалізацією: передньоперегородково-верхівкові, передньоверхівкові, передньобокові, задні, біфокальні; 4) за видом порушення кінетики стінки: акінетичні, дискінетичні; 5) за площею АЛШ: гемодинамічно незначущі (площа менше $25 \%$ ), гемодинамічно значущі (площа більше 25-30 \%); 6) за фракцією викиду (ФВ) (класифікація Stoney W.): аневризми з нормокінезом частини лівого шлуночка (ЛШ), що скорочується (ФВ 50 \%); АЛШ з гіпокінезом час- тини ЛШ, що скорочується (ФВ 30-50 \%); АЛШ з вираженим гіпокінезом ЛШ $(Ф \mathrm{~B} \leq 30 \%)[1,2]$.

Виділяють також анатомічні аневризми (істинні та несправжні, або псевдоаневризми) та функціональні [1]. Істинні анатомічні аневризми характеризуються тим, що діаметр устя аневризматичного мішка відповідає або перевищує максимальний діаметр самої аневризми, а ії̈ стінка представлена фіброзною тканиною. Для псевдоаневризми, або несправжньої аневризми, характерно, що розмір іiї устя в кілька разів менший iii максимального діаметра та зовнішня стінка представлена парієтальним листком перикарда. Більшість АЛШ передньоверхівкової локалізації є істинними, у той час як псевдоаневризми частіше локалізуються по задній стінці. Функціональні аневризми на ехокардіографії (ЕхоКГ) представлені акінетичними сегментами міокарда ЛШ [1, 2].

Мета. У статті наведено рідкісний випадок поєднання великої постінфарктної істинної АЛШ з несправжньою АЛШ, що виникла внаслідок розриву стінки істинної АЛШ. 
Результати та обговорення. Пацієнт К., 60 років, чоловік, поступив у Національний інститут серцевосудинної хірургії імені М. М. Амосова НАМН України 18.07.2015 р. з діагнозом: ішемічна хвороба серця (IXC), стенокардія напруження III-IV функціонального класу (ФК), постінфарктний кардіосклероз (гострий інфаркт міокарда (ГІМ) 17.06.2015р.), постінфарктна АЛШ, недостатність мітрального клапана II ст., гіпертонічна хвороба III ст., серцева недостатність III ст. Клінічний стан пацієнта на момент обстеження середньої тяжкості. Хворий скаржився на виражену задишку не лише під час фізичного навантаження, а й у стані спокою. В екстреному порядку пацієнту виконано низку діагностичних процедур.

За даними електрокардіограми виявлено: ритм синусовий, частота серцевих скорочень - 88 за 1 хвилину, рубцевий кардіосклероз задньої стінки ЛШ.

За даними рентгенографії органів грудної клітки виявлено збільшення контурів серця за рахунок лівих відділів.

При ЕхоКГ, що виконана за стандартною методикою, клапанна патологія в пацієнта не виявлена, порожнина ЛШ розширена (кінцево-діастолічний об’єм (КДО) 289 мл), скоротлива функція ЛШ знижена (ФВ 25 \%). Дилатація ЛШ переважала в базальних відділах, у ділянці верхівки ЛШ зберігав конусоподібну форму і мав задовільну контрактильну функцію. Товщина задньої стінки становила 3-4 мм, під час систоли не спостерігалося ії̈ потовщення та відзначалося аневризматичне вибухання іiї в заднє середостіння. Картину задньобазальної АЛШ яскраво демонструвала верхівкова двокамерна позиція (рисунок 1). В аневризму була залучена задня стінка ЛШ, починаючи від основи задньої стулки мітрального клапана до основи папілярних м'язів. Широку шийку АЛШ перетинали папілярні м'язи та хорди мітрального клапана. При цьому в порожнині аневризми спостерігався симптом спонтанного контрастування крові та визначалися плоскі пристінкові тромби завтовшки до 0,8 см. Кровотік між істинною порожниною ЛШ та аневризмою був нерестриктивний. Межі «шийки» АЛШ плавно переходили в «здорову» тканину міокарда. Діагноз великої задньобазальної істинної АЛШ не викликав сумніву. Однак позаду задньої стінки ЛШ візуалізувалася додаткова порожнина у вигляді осумкованого утворення з рідиною (рисунок 2). За даними кольорового доплера виявлено вузький канал, що пов'язував утворення з порожниною істинної базальної аневризми і, відповідно, порожниною ЛШ (рисунок 3). За даними кольорового доплерівського картування додаткова порожнина наповнювалася потоком у систолу з ЛШ, а в діастолу розвантажувалася в ЛШ (рисунок 4). Як результат ЕхоКГ-діагноз: поєднана задньобазальна АЛШ з проривом іiі стінки і формуванням псевдоаневризми ЛШ; постішемічна кардіоміопатія, мітральна недостатність, помірна легенева гіпертензія.

Пацієнту К. в НІССХ імені М. М. Амосова НАМН України виконано в екстреному порядку коронаровентрикулографію. На ангіограмі лівої коронарної артерії (ЛКА) в лівій боковій, краніальній та лівій косій проекціях з краніальним відхиленням виявлено помірні (до $50 \%$ ) стенози середньої третини огинаючої гілки ЛКА та помірний біфуркаційний стеноз передньої міжшлуночкової гілки ЛКА та діагональної гілки першого порядку (рисунки 5-7). На ангіограмі правої коронарної артерії (ПКА) візуалізується оклюзія дистальної третини артерії з колатералями з басейну ЛКА (рисунок 8). При лівій вентрикулографії в правій косій та лівій боковій проекціях виявлено, що порожнина лівого шлуночка значно розширена та деформована, скоротлива здатність його стінок різко знижена переважно за рахунок базальних відділів, де

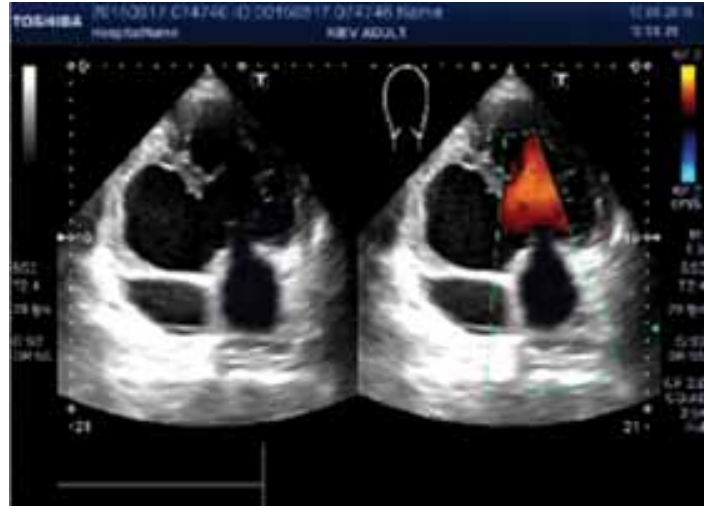

Рисунок 1. Верхівкова двокамерна позиція. Деформація порожнини ЛШ. Задньобазальна істинна АЛШ з пристінковими тромбами i псевдоаневризмою

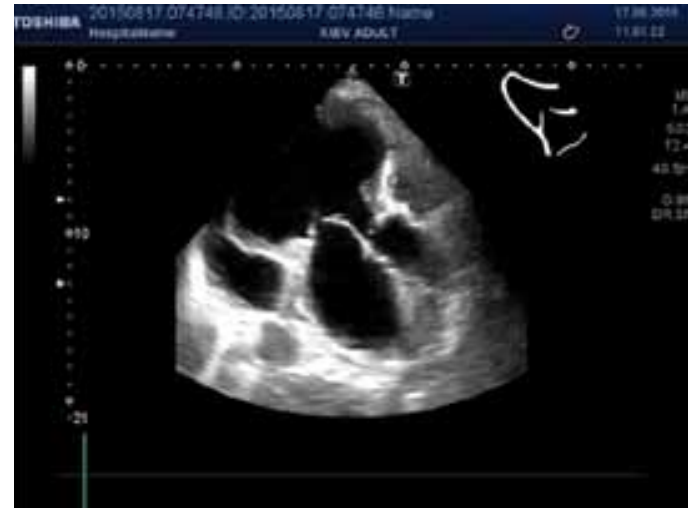

Рисунок 2. Парастернальна позиція по довгій осі. Позаду задньої стінки візуалізується додаткова порожнина, пов'язана вузьким каналом з порожниною ЛШ 


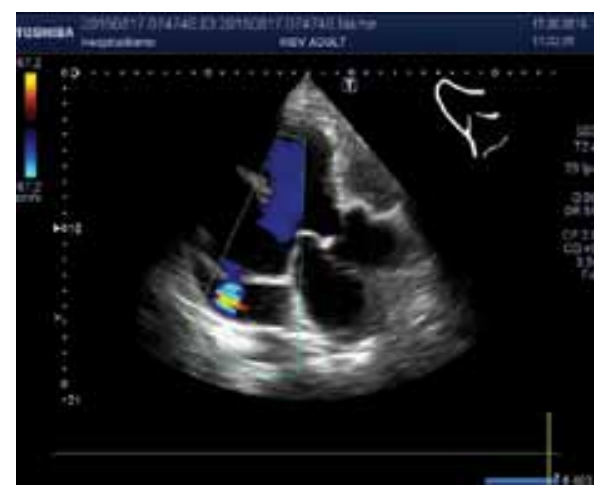

Рисунок 3. За даними кольорового доплерівського картування порожнина наповнюється струменем у систолу з ЛШ

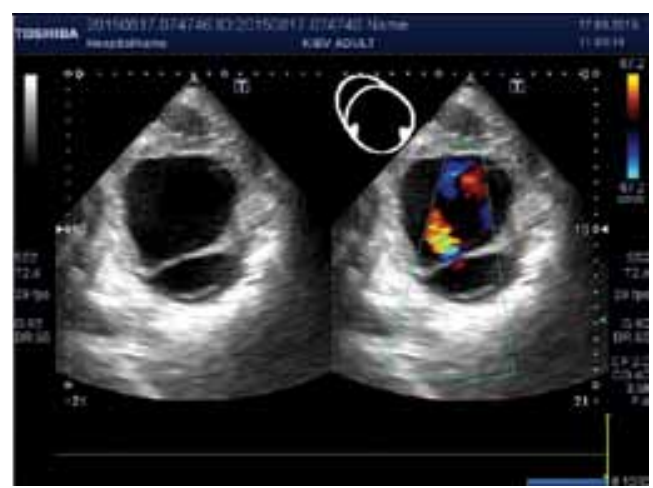

Рисунок 4. Парастернальний розріз ЛШ по короткій осі на рівні середнього відділу. $У$ діастолу псевдоаневризма розвантажується в порожнину ЛШ

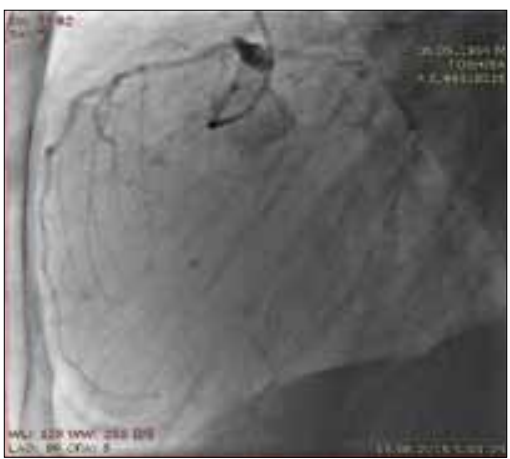

Рисунок 5. Ангіограма ЛКА в лівій бічній проекції

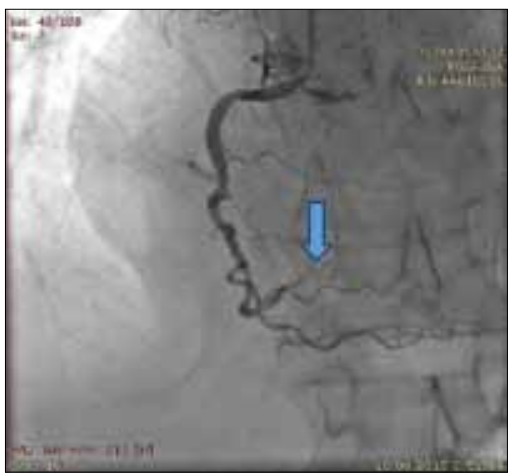

Рисунок 8. Ангіограма ПКА в краніальній проекції

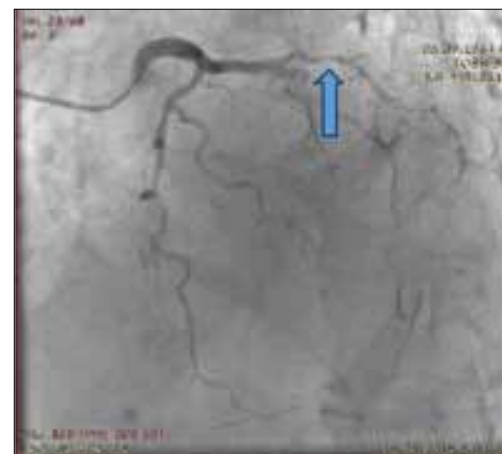

Рисунок 6. Ангіограма ЛКА в лівій косій проекції з краніальним відхиленням

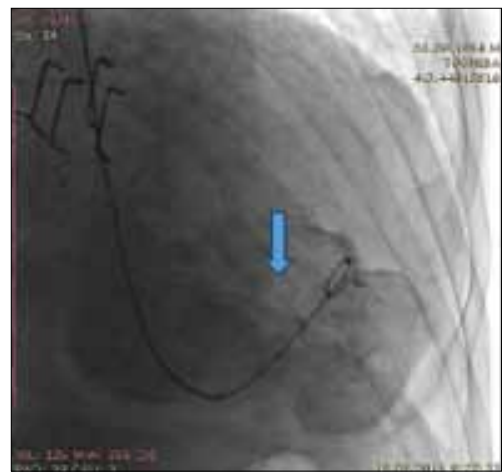

Рисунок 9. Ліва вентрикулографія в правій косій проекціі

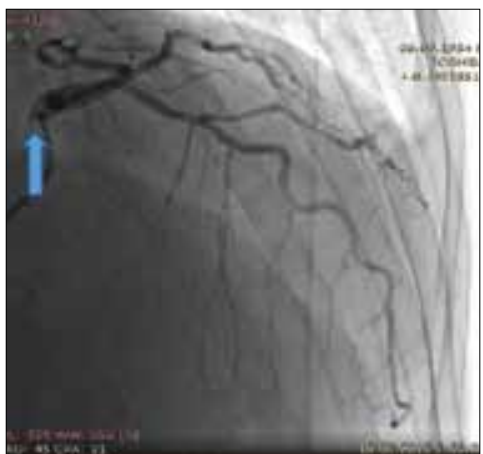

Рисунок 7. Ангіограма ЛКА в краніальній проекції

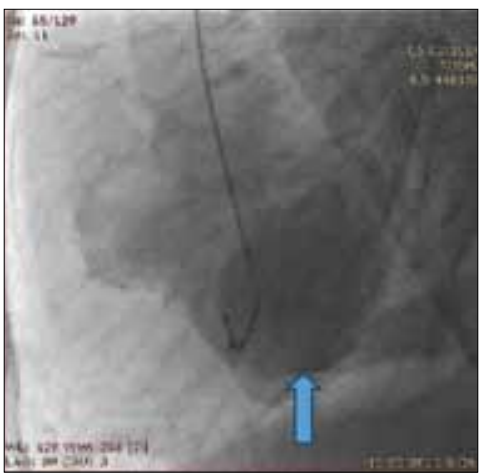

Рисунок 10. Ліва вентрикулографія в лівій боковій проекції визначається аневризматичне вип'ячування з виходом контрастної речовини в порожнину перикарда (рисунки 9, 10).

У зв'язку із загрозою тампонади пацієнту К. в екстреному порядку проведено оперативне лікування. Хворому виконано резекцію задньобокової АЛШ зі штучним кровообігом та на фоні використання внутрішньоаортальної балонної контрапульсації. Реабі- літаційний період у пацієнта перебігав без особливостей. Внутрішньобалонна контрапульсація припинена на другу добу після оперативного лікування. Хворому при виписуванні виконано ЕхоКГ-дослідження в усіх стандартних відведеннях (рисунок 11). Виявлено гіпокінезію задньонижньої стінки ЛШ в базальному відділі (зона пластики аневризми). Після проведеної пластики деформація порожнини ЛШ відсутня, мі- 
Левчишина О. В. / Клінічний випадок поєднання великої істинної аневризми лівого шлуночка, ускладненої...

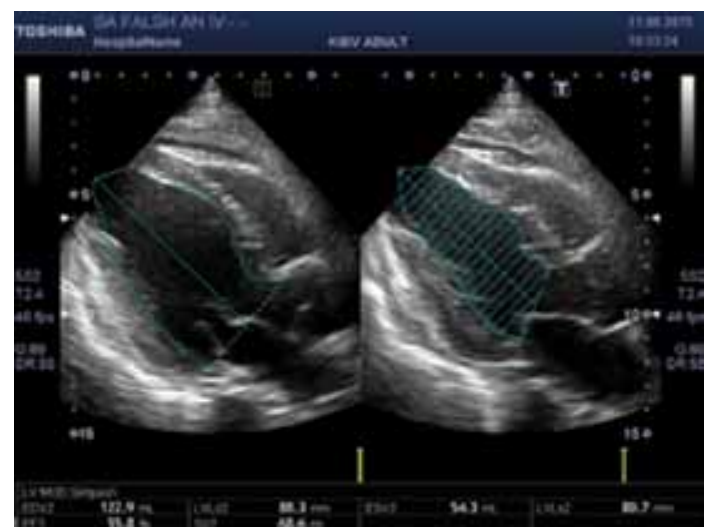

Рисунок 11. Після операції відсутня деформація порожнини ЛШ. Скоротливість та об'єм ЛШ в межах норми

тральний клапан збережений, загальна скоротливість покращилась (КДО - 123 мл, ФВ - $56 \%$ ).

Пацієнт переведений з Національного інституту серцево-судинної хірургії імені М. М. Амосова НАМН України до кардіологічного стаціонару за місцем проживання для проведення подальшої реабілітації на сьому добу після хірургічного лікування з відповідними рекомендаціями щодо подальшої медикаментозної терапії.

Висновки. Таким чином, після перенесеного трансмурального задньобокового ГІМ у пацієнта К. сформу- валася велика істинна АЛШ з вираженим зменшенням товщини стінки. Унаслідок подальшого стоншення стінки в інфарктній ділянці виник розрив, обмежений листками перикарда 3 подальшим гемоперикардом. У результаті сформувалась порожнина несправжньої АЛШ, що пов'язана невеликими рестриктивними воротами з істинною АЛШ. Точна діагностика та ургентне оперативне лікування дозволили пацієнту не лише вижити, а й зберегти якість життя.

\section{Список використаних джерел References}

1. Урсуленко ВИ, Гогаева ЕК, Якоб ЛВ, Дзахоева ЛС, Стародуб ЮС. Ургентное аорто - коронарное шунтирование на работающем сердце после тромболитической терапии на фоне острого коронарного синдрома. Кардіохірургія та інтервенційна кардіологія. 2015;2:35-8.

Ursulenko VI, Gogayeva OK, Yakob LV, Dzakhoieva LS, Starodub YuS. [Urgent off-pump coronary artery bypass grafting after thrombolysis in patient with acute coronary syndrome]. Kardiokhirurhiia ta interventsiina kardiolohiia. 2015;2:35-8. Russian.

2. Урсуленко ВИ. Хирургия осложненных форм ишемической болезни сердца. Киев; 2016. с. 11-2.

Ursulenko VI. [Surgery of the complicated forms of ischemic heart disease]. Kyiv; 2016. p. 11-2. Russian.

3. Davis R, Ebert P. Ventricular aneurysm: A clinicalpathologic correlation. Am. J. Cardiol. 1972;29:1-6. https://doi.org/10.1016/0002-9149(72)90408-0

\section{True and False Left Ventricular Aneurysm Combination: case report}

Levchyshyna O. V., Beshlyaga V. M., Rudenko A. V.

National Amosov Institute of Cardiovascular Surgery, Kyiv, Ukraine

Abstract. The article presents a case report of diagnosis and surgical treatment of a true and false left ventricular aneurysm combination in a patient after acute myocardial infarction. The patient $\mathrm{K}$. was admitted to the clinic with a diagnosis of coronary heart disease. Echocardiography revealed aneurysm of the posterior wall of the left ventricle. An additional cavity was visualized behind the posterior wall of the left ventricle. Emergency coronaroventriculography was performed in this patient. The left coronary artery angiogram revealed moderate (up to 50\%) stenoses of the middle third of circumflex artery, anterior interventricular artery, diagonal branch of the left coronary artery. The right coronary artery angiogram revealed occlusion of the distal third of the artery. The left ventriculography showed that the left ventricle cavity is significantly deformed, the wall contractility is reduced, and there is aneurysm in the left ventricle. Due to the threat of tamponade, emergency resection of the posterior-lateral left ventricular aneurysm was performed. According to the echocardiography, after the intervention, deformation of the left ventricle cavity was absent, the mitral valve was preserved, the contractility improved. The patient was transferred to a cardiac hospital at the place of residence. Accurate diagnosis and urgent surgical treatment helped to patient not only to survive but also to maintain the quality of life.

Keywords: left ventricular aneurysm, acute myocardial infarction, coronary heart disease.

Стаття надійшла в редакцію 05.09.2019 р. 